Israel

\section{Medicine confronts Jewish law}

\section{Rehovot}

TENSION between Israeli medicine and Jewish law, as embodied in the Torah, is growing. The immediate difficulty is that the practice of autopsies and transplants is being inhibited by the provisions of Jewish religious law that the body of a dead person must be treated with the utmost respect, must be buried quickly and in its entirety, and must "not be exploited".

Dr Mordechai Halperin, the physician and ordained rabbi who heads the Schlesinger Institute for Medical-Legal Research at the Orthodox-oriented Sha'arei Zedek Hospital in Jerusalem, says that one consequence is that autopsies cannot be carried out unless there is a "reasonable and immediate" prospect of the saving of human life

During the past few years, the numbers of autopsies carried out at Israeli hospitals have declined sharply, chiefly as a result of the Anatomy and Pathology Law of 1981 , a result of pressure from the religious parties, which requires that an autopsy requires not only the authorization of three

\section{Academies go west}

\section{Washington}

THE US National Academy of Sciences is going west. Together with the National Academy of Engineering, it has been given $\$ 20$ million by the Arnold and Mabel Beckman Foundation to establish a 50,000 square foot west-coast building complex consisting of an auditorium and meeting rooms at Irvine, California. The Irvine Company has donated a seven-acre site adjacent to the Irvine campus of the University of California, worth $\$ 6$ million.

Arnold Beckman, now 85, is the chairman and founder of Beckman Instruments Inc., of Fullerton, California, and has recently made multimillion-dollar donations to both of his former colleges, California Institute of Technology and the University of Illinois (see Nature 17 October, p.568). The gift to the national academies includes an endowment to maintain and stafi the building, which will be known as the Arnold and Mabel Beckman Center.

Beckman pointed out that California now leads the nation in memberships of both national academies. During fiscal year 1985, the academies and related institutions held more than 2,000 meetings in their east-coast buildings in Washington DC and Woods Hole, Massachusetts, but only 70 meetings were held west of Colorado. The new building will be used to support the full range of the academies' activities; Beckman has, however, expressed a particular desire that it should be used for the study of social and ethical issues arising from developments in science and engineering. Tim Beardsley physicians (as of old) but also the approval of the next of kin, and which allows the procedure to be blocked by almost any relative, even a distant cousin. At Halperin's own hospital, autopsies are now few and far between, perhaps fewer than a dozen a year. But he says that there is no necessary conflict between medicine and Jewish law, and that autopsies are no longer necessary for the training of medical students or even for confirming physicians' diagnoses. At Sha'arei Zedek, where full-scale autopsies require the consent of the hospital rabbi as well as that of a senior physician, post-mortem biopsies are quite common.

Elsewhere, the proportion of hospital deaths followed by post-mortem examinations has fallen to 10 per cent, but there are even fewer in Orthodox Jerusalem. Professor Haim Lichtig, a pathologist at the Haifa Technion medical school, says that students did not participate in a single autopsy last term, and that textbooks films and the examination of preserved organs are a poor substitute for the "the real thing".

Pathologists such as Dr Nina Hurwitz of the Kaplan Hospital also argue that autopsies remain a valuable means of "quality control" in the practice of medicine, and that post-mortem biopsies or non-invasive diagnostic techniques such as CATscanning are inadequate alternatives; the discrepancy between clinical and pathological diagnosis has remained obdurately unchanged for 40 years, she says.

The availability of organs for transplantation is similarly constrained. Halperin says that Jewish law would treat as "murder" the removal of organs from a body whose heart was beating but whose $E E G$ record was flat on the grounds that people had been known to recover from brain death. The removal of livers for transplantation would be permissible because artificial organs are not available, but kidney transplants are not always justifiable because kidney dialysis is possible. Halperin points out that life expectancy after kidney transplantation is not very different from that with dialysis

The strict application of the law is not always accepted. One paediatrician who is religious considers autopsies necessary and has performed them himself. On kidney transplants, he suggests that one kidney should be removed from a dying person who may still be maintained by a respirator. Even some members of the Orthodox establishment appear to recognize that changes are required. Former Chief Rabbi Shlomo Goren, who also served as Chief Chaplain to the Israeli Army, is reported to have been furious that skin for transplanting to injured Israeli soldiers has had to be imported from overseas.

Nechemia Meyers

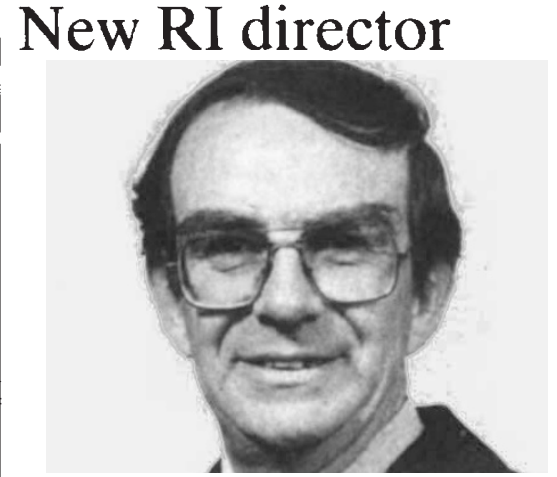

Profrssor John M. Thomas, at present professor and head of the department of physical chemistry at the University of Cambridge, will become director, resident professor and director of the Davy Faraday Research Laboratory in the Royal Institution, London, on 1 October 1986, in succession to Sir George Porter, who has been nominated as president of the Royal Society.

\section{French agriculture More help for farm lobby}

THE French government has taken further steps to strengthen the research base of its largest industry, agriculture. The ministers of agriculture, M. Henri Nallet, and of research, M. Hubert Curien, have announced a new programme to double government assistance to private research projects. This follows the earlier announcement that the agricultural research council (INRA) will be reorganizing its research programme so as to adapt more quickly to the opportunities in biotechnology (see Nature 24 October, p.660).

The stimulus for the new programme, which will take government support for private research to FF110 million a year, was apparently the discovery that agricultural and food companies spend only 0.25 per cent of their turnover on research.

Interestingly, the new assistance programme will focus on the downstream part of agriculture. The four principal themes are nutrition and toxicology, product quality, fermentation and food engineering. INSERM is also to pay more attention to the epidemiology of nutrition, while there is to be a global strategy of research on food and health.

The emphasis on food safety seems to derive in part from the recognition that if the European Communities manage to establish a central scheme for food and drug regulation, along the lines of the US Food and Drug Administration, French food exports could be jeopardized. But the government seems also to be anticipating a weakening of European price support for food and other produce and the more competitive market that would then come into being.

Robert Walgate 